\title{
Integration of Automobile Mechatronics Technology into the Curriculum of Automobile Trades Programmes at the Technical Colleges in Nigeria
}

DOI: https://doi.org/10.47175/rielsj.v2i1.195

\section{| Ariyo Samson Oluwatimilehin ${ }^{1}$ | Udogu Kingsley Chimezia² | | Mamman Danladi ${ }^{3}$ |}

1,2 Department of Industrial Technical Education, Faculty of Vocational and Technical Education, University of Nigeria, Nsukka, Nigeria

${ }^{3}$ Nigerian Defence Academy, Kaduna

${ }^{2}$ kingsley.udogu@unn.edu.ng

\begin{abstract}
The purpose of this study was to examine the perceptions of automobile industries workshop craftsmen in relation to the integration of automobile mechatronics technology into the curriculum of automobile trade programmes in technical colleges in Nigeria. Three research questions guided the study. A survey research design was adopted for the study. The population for the study is 31 comprising 23 automobile industries workshop craftsmen who are currently working in automobile companies in Enugu state, and eight (8) automobile trades' technical teachers in technical colleges in Enugu state. A structured questionnaire titled Instrument for Integrating Automobile Mechatronics Sub-systems (IIAMS) was used for data collection. Two experts from the Department of Industrial Technical Education, University of Nigeria, Nsukka, and one expert from Anambra Motor Manufacturing Company (ANAMCO) face validated the instrument. The reliability co-efficient of the instrument was found to be 0.87 using Cronbach Alpha. Data collected were analyzed using mean and standard deviation for the research questions, while $t$-test was used to test the null hypotheses. The results of the study indicate that that automobile craftsmen find difficulties in servicing some automobile mechatronics sub-systems, while 16 mechatronics sub-systems were agreed on to be integrated into the automobile curriculum. It was recommended that these mechatronics sub-systems should be integrated into technical college curriculum and that technical colleges should partner with automobile industries for effective training of craftsmen. The study will contribute positively to the understanding of automobile mechatronics technology, and how it can be integrated into the curriculum.

KEYWORDS

technical education: craftsmen: mechatronics: curriculum
\end{abstract}

\section{INTRODUCTION}

The integration of automobile mechatronics into the curriculum is important if automobile technology graduates of technical colleges are to perform and fit well into the world of work. According to Aruku, (2007) it was observed that technical college graduates of automobile technology are finding it difficult to service and repair automobiles that possess mechatronics system, this is due to the fact that the curriculum that is used to teach them does not include the mechatronics sub-systems.

Motor Vehicle Mechanic's Work is one of the automobile trades offered at the craft, master craft and advanced craft levels in technical colleges. According to Audu et al. (2014), 
Motor Vehicle Mechanic (MVM) work is a TVET program which involves the acquisition of scientific knowledge in design, selection of materials, construction, operation and maintenance of motor vehicles. MVMW is designed to give training and impart the necessary skills leading to the production of technicians and other skilled personnel who will be enterprising and self-reliant (National Board for Technical Education, 2003). MVMW is designed to produce competent motor vehicle craftsmen for Nigeria technical and industrial development (Aruku, 2007). In other words, MVMW graduates are expected to diagnose service and completely repair any fault relating to the conventionalautomobile assembly main unit to the manufacturers specification.

In recent days there is a growing trend towards the use of advanced technology for thedesign manufacture, and rapid development of modern vehicles to a very sophisticated level. Modern vehicle design is driven by the need for increased comfort, safety and security. As a result automobiles are becoming intelligent and increasingly reliant on electronics by offering compact, highly advanced components and modules used in communication, safety, information power train systems, radio frequency and sensing technologies. According to Akpakpavi (2014), modern automobiles are a blend of 20th century and $21^{\text {st }}$ century technology. Draganov, Vasileva \& Traykov stated that modern cars are as much electronic as they are mechanical, thus creating a new area called autotronic. According to Ezeama et al (2016) autotronics is automobile mechatronics. Mechatronics according to the Yasakawa Electric Company is a word composed of "mecha" from the mechanism and the "tronics" from electronics (Akshay, Pradip, Prashant, Shubham\& Rahul, 2016). Mechatronics defined as, the synergistic integration of mechanical engineering, with electronics and intelligent computer control in the design and manufacturing of industrial products and processes (Horacio, 2011).

Mechatronics therefore is a new field of engineering which is designed to produce an allround engineer that would fit into virtually all engineering activities in industries including machine vision, automotive engineering, computer aided design, sensing and control systems, mobile applications, robotics and so on. Automobile Mechatronics can be divided into two aspects: one is the automotive electronic control devices which were integrated with the mechanical system in the vehicle applications. Automotive electronic control is a combination of mechanical and electrical devices, they include engine power, sensor system control (images, acceleration, pressure or temperature, etc.), electro-mechanical control (Xby-wire, electronic fuel injection systems, ABS, skid control, electronic control suspension, electronically controlled automatic transmission etc.); the other aspect is the on board autotronic devices which are electronic devices that can be operated independently in a car environment, they are not directly related to the automobile's performance, safety, or control, they include integrated on board machines, satellite navigation systems, audio-visual entertainment systems, etc. As a result, the automobiles have been integrated with electronic control technologies such as sensors, micro-controller unit (MCU), the image and display (camera \& display), on board unit (OBU), satellite positioning, wireless communications, semiconductors, power devices, and even portable devices are used to connect vehicles with the customer service center via wireless links (Ezeama, Obe \& Ede, 2016). Similarly, Gurjeevan, Kamal, Gazal and Sukhjinder (2014) stated that more and more mechatronic systems were investigated in automotive application, including antilock braking systems, supplemental restraint systems, cruise control, and traction control. Mechatronic systems play a more important role for improving automotive functionality, safety, economy and comfort, and the designed functions assist the driver to prevent unstable or unpredictable behaviour and to stabilize the motion of the automobile.The mechatronics discipline is therefore attracting students to be part of the new era of industrialization to support advanced 
product development, and to enable the interdisciplinary engineer to look forward to a high quality of job satisfaction with enhanced employment prospects. This new concept requires strong scientific background and experimental techniques as well as a broad knowledge in engineering. This requirement can only be realized through appropriate and adequate education and training in the mechatronics engineering discipline (Abubakar and Robert, Undated).

As technology improvements in the vehicles and the manufacturing process dictate that jobs and skills change, so too must the educational offerings change as MVM trainers are expected to bring about the change. According to Crunkilton \& Finch (1999), contemporary vocational curriculum must be responsive to a constantly changing world of work. New developments in various fields should be incorporated into the curriculum so that graduates can compete for jobs and, once they have jobs, achieve their greatest potential. However, observation by the researchers revealed that the current curriculum for teaching MVMW was reviewed in 2003, as such, it lacks the components of automobile mechatronics which would have equipped its recipients with emerging skills for repairing and servicing modern vehicles.Supporting this view, Usman (2007) stated that the orthodox skills of auto technicians have been rendered valueless by emergence of computer technology in modern automobiles, and auto technicians lack knowledge and high technician skills needed to repair modern automobiles. It therefore follows that the learning contents of MVMW and skills that can be acquired through the curriculum is not in tandem with state of the arts requirements for automobile maintenance. The resultant effect of this situation is that the automobile craftsmen being produced in the technical colleges possess insufficient $21^{\text {st }}$ century automechanic skills required for employment in the automobile industries thereby worsening the situation of unemployment in Nigeria.

The essential ingredients that ensure a successful mechatronics course delivery are adequate provision of curriculum and delivery. The content of MVM program in the technical colleges must therefore beupdated in tandem with the new technological developments as well as advancements in the automobile industry, in order to equip the learners with relevant knowledge and skills for troubleshooting, servicing and maintaining modern vehicles. Supporting this view, the United Nation Educational Scientific and Cultural Organization (UNESCO, 1999) observed that the mismatch of curricula in technical and vocational education with the needs of the industries is a key issue not only in African countries but also globally. It is therefore on the premise of the mismatch between MVMW curriculum and the emerging skills required for employment in the automobile industry that this study is justified to integrate automobile mechatronics technology into the curriculum of MVMW trade at the technical colleges in Nigeria.

\section{RESEARCH METHODS}

Survey research design was adopted for this study. Nworgu (2006) stated that a survey research design is one in which a group of people or items are studied by collecting and analyzing data from a few people or items considered to be the representative of the entire group. The study was carried out in Enugu State. The population for the study is 31 comprising 23 automobile industries workshop craftsmen who are currently working in automobile companies in Enugu state, and eight (8) automobile trades' technical teachers in NBTE accredited technical colleges in Enugu state.

The instrument used for data collection was a structured questionnaire developed by the authors titled Instrument for Integrating Automobile Mechatronics Technology systems (IIAMTS). This questionnaire was divided into three sections, The first section had seventeen items that centred on mechatronics subsystems that craftsmen find difficult to 
service, the response categories of the instrument used was Very Difficult (VD), Difficult (D), Moderately difficult (MD) and Not Difficult (ND), which were assigned numerical values of 4, 3, 2, and 1 respectively. The second section had seventeen items and was used to identify the automonbile mechatronics technology systems that should be integrated into the curriculum. The instrument has a 4 point response scale of Strongly Agree (SA), Agree (A), Disagree (D) and Strongly Disagree (SD) with the numerical values of 4, 3, 2 and 1 respectively. The third section consisted of seventeen items measuring the level of awareness of automobile craftsmen in automobile mechatronics technology systems, with a response scale of Highly Aware (HA), Aware (A), Moderately Aware (MA) and Not Aware (NA), they had a numerical scale of 4, 3, 2, and 1 respectively. The instrument was subjected to face and content validation by two experts from the Department of Industrial technical Education, University of Nigeria Nsukka, and one expert from Anambra Motor Manufacturing Company (ANAMCO), Enugu State to attest the appropriateness of the instrument in measuring what it is intended to measure. The instrument was trial tested on 6 automobile craftsmen in Anambra State using Cronbach Alpha formula which yielded reliability co-efficient of 0.87 . The data was collected by administering and retrieving the structured questionnaire directly on the respondents by the researchers and two research assistants (one from the technical college and another from the automobile industry).

The data collected from the study was analyzed using mean and standard deviation (SD) for answering the research questions and t-test for testing the null hypotheses at probability level of 0.05. Any item with a mean value of 2.50 and above was regarded as required/Agreed/Aware.Required, while any item with a mean below 2.50 was regarded as not required/Agreed/Aware. Data analyses were carried out using SPSS version 22.0 as statistical packages.

\section{RESULTS AND DISCUSSION}

Table 1. Mean and T-test Analysis of the Responses of Automobile Craftsmen and Automobile Teachers on their Level of Awareness of Automobile Mechatronics Sub-systems

\begin{tabular}{llllcll}
\hline S/N & Item Statements & $\mathbf{X}$ & SD & Decision & Sig. & Remark \\
\hline 1 & Antilock brake systems & 3.56 & HA & .51 & .808 & NS \\
2 & Electronic fuel injection systems & 2.69 & A & .79 & .056 & NS \\
3 & Variable valve timing intelligence & 1.56 & MA & .63 & .033 & NS \\
4 & Traction control unit & 1.38 & NA & .50 & .590 & NS \\
5 & Stability control system & 1.63 & MA & .62 & .614 & NS \\
6 & Engine control unit & 2.44 & MA & .96 & .316 & NS \\
7 & Slip regulation system & 1.44 & NA & .51 & .428 & NS \\
8 & Stability control system & 1.81 & MA & .75 & .339 & NS \\
9 & Active suspension system & 1.81 & MA & .98 & .006 & NS \\
10 & Steering assist & 2.06 & MA & .68 & .144 & NS \\
11 & Cruise control & 2.63 & A & .72 & .385 & NS \\
12 & Steer-by-wire system & 1.25 & NA & .45 & .039 & NS \\
13 & Smart Actuator & 1.43 & NA & .51 & .206 & NS \\
14 & Bose suspension system & 1.62 & MA & .81 & .768 & NS \\
15 & Magnetic levitation system & 1.25 & NA & .44 & .343 & NS \\
16 & Electromagnetic valve actuator & 1.37 & NA & .50 & .590 & NS \\
17 & Powertrain control module & 1.62 & MA & .62 & .152 & NS \\
18 & Dynamic headlamps & 1.89 & MA & .81 & .057 & NS \\
\hline
\end{tabular}

Note X = Grand Mean; SD= Standard Deviation; NS = Not Significant; VA = Very Aware; A = Aware; MA = Moderately Aware; NA = Not Aware; $\mathrm{H}_{0}=$ Null Hypothesis. 
From the data presented in table 1, it can be observed that automobile craftsmen were highly aware of one mechatronic sub-system while they were aware of two sub-systems (2.63-3.56). The craftsmen were also moderately aware of nine mechatronics sub-systems (1.56-2.44) while they were not aware of six mechatronics sub-systems (1.25-1.44). The table also revealed that there was no significant difference on the responses of automobile trade teachers and automobile craftsmen on their level of awareness of different mechatronics subsystems, since the level of significance was greater than $.05(\mathrm{P}>0.05)$. Therefore, the hypothesis that states that there is no significant difference between the mean responses of technical teachers of automobile trades and automobile craftsmen working in industries on their level of awareness of mechatronics sub-systems was accepted.

Table 2. Mean and t-test Analysis of the Responses of Automobile Craftsmen and MVMW Teachers on the Automobile Mechatronics Technology systems they find Difficult to Service

\begin{tabular}{lllllll}
\hline S/N & Item Statements & $\mathbf{X}$ & SD & Decision & Sig. & Remark \\
\hline 1 & Antilock brake systems & 1.20 & ND & 0.41 & .705 & NS \\
2 & Electronic fuel injection systems & 1.27 & ND & 0.46 & .701 & NS \\
3 & Variable valve timing intelligence & 3.47 & D & 0.64 & .033 & NS \\
4 & Traction control unit & 3.20 & D & 0.56 & .351 & NS \\
5 & Stability control system & 3.20 & D & 0.56 & .351 & NS \\
6 & Engine control unit & 3.27 & D & 0.70 & .823 & NS \\
7 & Slip regulation system & 3.20 & D & 0.68 & .455 & NS \\
8 & Stability control system & 3.33 & D & 0.72 & .276 & NS \\
9 & Active suspension system & 3.33 & D & 0.62 & .765 & NS \\
10 & Steering assist & 3.13 & D & 0.74 & .631 & NS \\
11 & Cruise control & 3.27 & D & 0.59 & .542 & NS \\
12 & Steer-by-wire system & 3.47 & D & 0.52 & .745 & NS \\
13 & Smart Actuator & 3.33 & D & 0.62 & .765 & NS \\
14 & Bose suspension system & 3.46 & D & 0.64 & .558 & NS \\
15 & Magnetic levitation system & 3.60 & VD & 0.51 & .055 & NS \\
16 & Electromagnetic valve actuator & 3.46 & D & 0.52 & .517 & NS \\
17 & Powertrain control module & 3.13 & D & 0.74 & .064 & NS \\
18 & Dynamic headlamps & 3.27 & D & 0.59 & .739 & NS \\
\hline
\end{tabular}

Note: $\mathrm{X}=$ Grand Mean; $\mathrm{SD}=$ Standard Deviation; NS = Not Significant; VD = Very Difficult; $\mathrm{D}=$ Difficult; MD = Moderately Difficult; ND = Not Difficult; $\mathbf{H}_{0}=$ Null Hypothesis.

Data presented in Table 2 shows that the automobile mechatronics sub-systems with mean values from $1.20-1.27$ are not found to be difficult to service by automobile craftsmen while the mechatronics sub-systems with a mean values range of 3.13-3.60 are found to be difficult to service by automobile craftsmen. Table also shows that all the 18 mechatronics sub-systems items had their significant value to be greater than $.05(\mathrm{P}>0.05)$. This indicated that, there was no significant difference between the mean responses of technical teachers and automobile craftsmen on the mechatronics sub-systems they find difficult to service, therefore the hypothesis which stated that there is no significant difference between the mean responses of technical teachers of automobile trades and automobile craftsmen working in industries on the mechatronics sub-system they find difficult was upheld. 
Table 3. Mean and T-test Analysis of the Responses of Automobile Craftsmen and Automobile Teachers on the Mechatronics Sub-systems that should be Integrated into the

\section{Curriculum}

\begin{tabular}{|c|c|c|c|c|c|c|}
\hline $\mathbf{S} / \mathbf{N}$ & Item Statements & $\mathbf{X}$ & SD & Decision & Sig. & Remark \\
\hline 1 & Antilock brake systems & 1.50 & $\mathrm{D}$ & 0.68 & .082 & NS \\
\hline 2 & Electronic fuel injection systems & 1.47 & SD & 0.63 & .597 & NS \\
\hline 3 & Variable valve timing intelligence & 3.03 & A & 0.61 & .141 & NS \\
\hline 4 & Traction control unit & 3.33 & A & 0.61 & .845 & NS \\
\hline 5 & Stability control system & 3.30 & $\mathrm{~A}$ & 0.60 & .587 & NS \\
\hline 6 & Engine control unit & 3.27 & A & 0.83 & .246 & NS \\
\hline 7 & Slip regulation system & 3.07 & $\mathrm{~A}$ & 0.83 & .055 & NS \\
\hline 8 & Stability control system & 3.77 & SA & 0.50 & .195 & NS \\
\hline 9 & Active suspension system & 3.40 & A & 0.67 & .533 & NS \\
\hline 10 & Steering assist & 3.37 & A & 0.67 & .675 & NS \\
\hline 11 & Cruise control & 3.47 & $\mathrm{~A}$ & 0.57 & .207 & NS \\
\hline 12 & Steer-by-wire system & 3.87 & SA & 0.43 & .345 & NS \\
\hline 13 & Smart Actuator & 3.60 & SA & 0.49 & .567 & NS \\
\hline 14 & Bose suspension system & 3.03 & A & 0.72 & .478 & NS \\
\hline 15 & Magnetic levitation system & 3.53 & SA & 0.68 & .286 & NS \\
\hline 16 & Electromagnetic valve actuator & 3.40 & A & 0.56 & .238 & NS \\
\hline 17 & Powertrain control module & 3.83 & SA & 0.46 & .322 & NS \\
\hline 18 & Dynamic headlamps & 3.50 & SA & 0.57 & .748 & NS \\
\hline
\end{tabular}

Note: $\mathrm{X}=$ Grand Mean; $\mathrm{SD}=$ Standard Deviation; $\mathbf{N S}$ = Not Significant; $\mathrm{SA}$ = Strongly Agree; $\mathrm{A}=$ Agree; D = Disagree; $\mathbf{S D}=$ Strongly Disagree; $\mathrm{H}_{0}=$ Null Hypothesis .

Data presented in Table 3 shows that automobile craftsmen agreed that mechatronics subsystems with mean values from 3.03 - 3.83 should be integrated into the Curriculum of Automobile Trades programmes of Technical Colleges in Nigeria, while they disagreed on the inclusion of mechatronics sub-systems with mean values from $1.47-1.50$. Table 2 also shows that all the 18 mechatronics sub-systems items in relation to their integration into the automobile curriculum had their significant value to be greater than $.05(\mathrm{P}>0.05)$. This indicated that, there was no significant difference between the mean responses of teachers and automobile craftsmen on the mechatronics sub-systems that should be integrated into the automobile curriculum of technical colleges, therefore the hypothesis which stated that there is no significant difference between the mean responses of technical teachers of automobile trades and automobile craftsmen working in industries on the mechatronics subsystem that should be integrated into the curriculum was accepted.

The findings of the study showed that 16 mechatronics sub-systems were found to be difficult to service by automobile craftsmen and automobile teachers. This finding is in agreement with Olayinka \& Oyenuga (2010) who stated that there have been complex changes in the systems and components of automobiles in Nigeria, which automobile students in technical colleges find difficult to service. This is because these new developments like mechatronics sub-systems are not reflected in the curriculum that is used to train automobile craftsmen in technical colleges.

Further, the results of the study also showed that 16 automobile mechatronics technology sub-systems agreed on by automobile teachers and craftsmen in the industries to be integrated into the curriculum of automobile trades in technical colleges. This finding is in agreement with Schwaller (1993) and Nice (2001) who agreed that the incorporation of new technologies in modern automobiles is important, Schwaller (1993) insisted that automobile service personnel need not only the understanding of the parts, nomenclature and operation 
but also requires great deal of knowledge and skills in the selection and correct application of tools, correct procedures of fault diagnosis, disassembling and reassembling. Meeting these requirements must come from the identification and integration of the relevant technologies and covering all their relevant components in automobile technology curriculum.

Finally, the findings in the study also revealed that automobile teachers and craftsmen were not aware of some automobile mechatronics sub-systems. This is in agreement with Olayinka \& Oyenuga (2010) who observed the influence of technology on the automobile industry, because of this technological influence it might be difficult for automobile teachers to keep up with the current new and emerging technologies in the automobile world.

\section{CONCLUSION}

The study identified the automobile mechatronics sub-systems that are important to teach new technological developments in automobile technology and at the same time integrate these sub-systems identified into existing modules of the automobile trade curriculum of technical colleges in Nigeria. It is hoped that if all these sub-systems are taken into consideration in the training of auto-mechanics craftsmen in the technical colleges, the students will graduate from the technical colleges with the knowledge and practical skills required to meet the needs of the industry and evolving technological developments in the automobile industries. Consequently, the students will be able to face the challenges of work in the automobile industry if employed, establish their own workshop in the absence of paid employment, become employers of labour instead of depending solely on paid employment and thereby contribute their own quota to the industrial development of Nigeria and the world at large.

Based on the findings of the study, the following recommendations were made:

- The National Board for Technical Education (NBTE) should conduct a review of curriculum for automobile trade programs in technical colleges with a view to include the new mechatronics sub-systems in automobiles.

- Government and Administrators of technical colleges in Nigeria should ensure the provision of adequate workshop and equipment for an effective implementation of the curriculum to be reviewed. The teaching staff (teachers/instructors) should undergo appropriate retraining to update their knowledge and skills for effective implementation of the new curriculum.

- Constant seminars, workshops and conferences should be organized for technical college teachers/instructors and students to keep abreast of the new developments in automobile technology. Technical colleges should also partner with automobile industries so that they will keep up with the current trend of new technologies in the automobile industry.

\section{REFERENCES}

Akpakpavi, M. (2014). Modern automobile vehicle repair practices in micro, small and medium scale garages in Ghana. International Journal of Science, Technology and Society, 2(6), 216-222.

Agbata, V. I. N. (2000) Relevance of the Technical College Auto-mechanics Curriculum to the automobile industry in Anambra State. An unpublished M.Ed Thesis, University of Nigeria Nsukka. 
Akshay, B. Z., Pradip, R. L., Prashant, W. W., Shubham, A. S., Rahul, R. G. (2016). Evolution of the Mechatronic systems and its Overview. International Journal for Research in Applied Science \& Engineering Technology (IJRASET).4(11), 49-54.

Aruku, A. S. (2007). The relevance of motor mechanics curriculum to the entrepreneurial needs of motor mechanic graduates of technical colleges in Enugu State. Unpublished M.Ed. Thesis. University of Nigeria, Nssuka.

Audu, R., Aede, H. B. M., Yusri B K, Muhammad, S. B. S. \& Inti, M. M. (2014). Retraining needs of motor vehicle mechanics teachers at technical college level. Journal of Technical Education and Training (JTET), 6 (1), 11- 22.

Crunkilton, J., \& Finch, C. (1999) Curriculum Development in Vocational and Technical Education 5th edition. Boston, MA: Allyn and Bacon.

Draganov, V., Vasileva, T., \& Traykov, B. (2007). Autotronics Course-An Inovative Approach in Automotive Mechatronics Education. International virtual journal for science, techniques and innovations for the industry, 8-9.

Ezeama, A. O., Obe, P. I. and Ede, E. O. (2016) Assessment of capacity building needs among motor vehicle mechanics trainers for the use of auto scan tools.Nigerian Journal of Technology (NIJOTECH) , 35 (4), $805-813$.

Ezeama, A.O., Oguejiofor, V. I. \& Uzoejinwa, B. B. (2016).Integration of mechatronics and autotronics in technical education for greater technological innovation in Nigeria. International Technology Research Journal (INTERJ) 4(1), 21- 30.

Elobuike, H. U. (1999). Relevance of Technical College in Electrical/Electronics and Mechanical/Automobile programs to the needs of industries in Anambra, Eboyi and Enugu States. (Unpublished doctoral dissertation).University of Nigeria Nsukka

Enemaili, J. D. (1991). An Evaluation of the Quality of Training Received and its Influence on the Job Performance of Technical College graduates. (Unpublished M.Ed Thesis) University of Nigeria Nsukka.

Federal Republic of Nigeria (2013). National policy on education - $6^{\text {th }}$ Edition. LagosNigeria: NERDC Press.

Gurjeevan, S., Kamal, K., Gazal, P.A., Sukhjinder S. (2014).Use of Mechatronics in Today's Industry: A $\quad$ Review. $\quad$ Retrieved from https://www.researchgate.net/publication/289871726

Hsu, T. R., Wang, J. C., Barez, F., Furman, B., Hsu, P., Reischl, P. (1995). An undergraduate curriculum in mechatronic systems engineering. In: Proc. International Mechanical Engineering Congress and Exposition, San Francisco, CA, November 12- 17, 1995.

Horacio Martínez-Alfaro (2011). Advances in mechatronics, INTECH. DOI: 10.5772/875

Jacob Fraden (2004). Handbook of Modern Sensors Physics, Designs, and Applications, 3rd edition, Springer-Verlag New York, Inc.

National Board for Technical Education (2001). Revised national technical certificate and advance national revised technical certificate programmers for motor vehicle mechanics work trade curriculum and course specification. Kaduna: NBTE.

National Board for Technical Education (2003). National technical certificate and advanced national technical certificate curriculum and module specifications in motor vehicle mechanics' work. Kaduna-Nigeria: NBTE Press.

Nice, K. (2001). How car computers work. Retrieved from http://www.Howstuffworks.com.

Nworgu B. (2006). Educational Research: Basic Issues and Methodology. Ibadan: Windon Publishers Ltd

Okorie, J.U. (2001). Vocational industrial education. Bauchi: League of Publishers. 
Olayinka, O. and Oyenuga, A. (2010). Integration of Automobile Technological Developments into Nigeria Technical College Motor Vehicle Mechanics Work Curriculum. Academic Leadership Journal 8(2)

Schwaller, A. E. (1993). Motor Automotive Technology. New York: Delmar publishers Inc. Stuart, S. (2007). Autotronics: implications for automotive related training programs standards based upon emerging technologies. An unpublished Doctor of Education dissertation of Oregon State University.

UNESCO (1999). Establishing Partnership in Technical and Vocational Education. A Seminar for Key Personnel from Africa, Asia, Berlin Germany 02-12 May. 